B I O S C I E N C E

J O U R N A L

\title{
SPATIAL DISTRIBUTION OF ANTI-RABIES POST-EXPOSURE \\ TREATMENTS ASSOCIATED WITH THE DECENTRALIZATION PROCESS IN BELO HORIZONTE, 2007 TO 2011
}

\author{
Marcelle Aparecida de OLIVEIRA ${ }^{1}$ (i), Tiago Mendonça de OLIVEIRA $^{1}$ (iD), \\ Misael Enrique Oviedo PASTRANA ${ }^{2}$ iD, Renato Martins DUARTE ${ }^{3,4}$ iD, \\ Soraia de Araújo DINIZ ${ }^{5}$ iD, Marcos Xavier SILVA ${ }^{1}$ iD
}

\begin{abstract}
${ }^{1}$ Preventive Veterinary Medicine Department, School of Veterinary, Federal University of Minas Gerais, Belo Horizonte, Minas Gerais, Brazil.
${ }^{2}$ Corporación Colombiana de Investigación Agropecuaria, Centro de investigación Turipaná, Cereté, Córdoba, Colombia.

${ }^{3}$ Prefecture of Belo Horizonte, Belo Horizonte, Minas Gerais, Brazil.

${ }^{4}$ Postgraduate Program in Preventive Veterinary Medicine, School of Veterinary, Federal University of Minas Gerais, Belo Horizonte, Minas Gerais, Brazil.

${ }^{5}$ Institute of Agricultural Sciences, Veterinary Medicine Course, Federal University of Vale of Jequitinhonha and Mucuri, Unaí, Minas Gerais, Brazil.
\end{abstract}

Corresponding author:

Marcos Xavier Silva

Email: vetmarcosxavier@hotmail.com

How to cite: OLIVEIRA, M.A., et al. Spatial distribution of anti-rabies post-exposure treatments associated with the decentralization process in Belo Horizonte, 2007 to 2011. Bioscience Journal. 2021, 37, e37084. https://doi.org/10.14393/BJ-v37n0a2021-54091

\begin{abstract}
Cases of canine attacks on people are reported because of the proximity of the dog to the households in several Brazilian cities. In the present study, we aim to evaluate post-exposure anti-rabies treatments with canine accidents between the years 2007 to 2011 in Belo Horizonte - MG. Duly notified data were obtained from the National System of Notifiable Diseases (SINAN). The spatial characteristics of the cases during the period of the study referred to the neighborhoods and the nine sanitary districts of the municipality of Belo Horizonte - MG. For georeferencing and spatial analysis, we used the software Maporama to identify the coordinates and the Geographic Information System ArcGIS for mapping. Considering the 6.153 prophylactic services that were georeferenced, the Norte, Venda Nova, Leste, and Centro Sul regions were highlighted due to the higher frequency of registered cases. It is suggested that an integrative action focused on canine population control, health education and epidemiological surveillance studies could contribute to the reduction of canine aggression cases.
\end{abstract}

Keywords: Anthropozoonotic Infection. Canine Accidents. Prevention. Rabies. Sinan. Zoonoses.

\section{Introduction}

Human rabies is a viral anthropozoonotic disease that affects the central nervous system (CNS) characterized by encephalitis. It is a preventable disease, yet it remains a major cause of human mortality in many countries, posing a major challenge for health authorities (Brasil 2011; Frias et al. 2011; Garc 2011). Dogs are considered the preferred pets of modern society. Due to the inclusion of the dog in the family environment, its importance related to zoonotic and the probability of occurrences of aggressions has been thematic in Public Health, not only because of their sequelae but also because of the costs they produce to health services (Schneider et al. 1996; Rosado et al. 2007) since it is mandatory to administer human antirabies post-exposure prophylaxis, which is available at public health centers located in the municipalities.

Data regarding dog bites are mainly obtained from studies from hospitals and health services offered by the Unified Health System (SUS). The epidemiological analysis of these data, as well as the identification 
of geographic areas associated with cases of canine aggression, could help to prevent many fatal attacks by using appropriate and effective prophylactic measures (Rosado et al. 2007; Cabral et al. 2018).

The establishment of the National Rabies Prophylaxis Program (PNPR) in the 1970s and the SUS health care decentralization since 1990 contributed to control the rabies virus transmission through regional actions, such as the proper treatment and vaccination for human, dogs, and cats (Schneider et al. 1996; Carvalho et al. 2002).

The decentralization of health services allowed the systematic use of information in a decentralized way, assisting professionals in health planning, intervention, and promotion (Mendes et al. 2000). In addition, decentralization allowed primary care for patients in health centers close to their homes. In the most complex cases, patients would be referred to as "second care" in more specialized hospitals or health centers.

According to the Ministry of Health (Brasil 2020), in the period from 2010 to 2020, 38 cases of human rabies were registered, and in 2014, there were no cases. Of these cases, nine had the dog as an aggressor animal, twenty for bats, four for non-human primates, four for felines, and in one of them it was not possible to identify the aggressor animal (Brasil 2020). In the city of Belo Horizonte there have been no cases of rabies in domestic animals since 1989 and since 1984 there have been no records in humans, but in bats, there are still records of the disease, so dogs and cats should be vaccinated. Between 2007 and $2019,81.70 \%$ of the more than 7.5 million notifications of post-exposure human anti-rabies prophylactic care were due to assaults involving domestic dogs (Brasil 2020).

In order to assist the health professionals and the public agents in the decision making, the spatial analysis is used to support the choices related to the prevention of diseases and injuries (Carpenter 2011; Barbosa et al. 2014). Its application in Health is highlighted at the epidemiological surveillance since the spatial analysis of diseases allows: to demonstrate possible vulnerabilities; helping the decision-making setting priorities; in the implementation of preventive measures, treatment, and health promotion (Rothman 1990; Magalhães et al. 2006). Considering the importance and need to assess the epidemiology of post-exposure rabies prophylaxis with canine accidents in Belo Horizonte - MG, the present study aimed to characterize this care spatially between the years 2007 to 2011.

\section{Material and Methods}

An observational, sectional, and retrospective study was carried out from a database made available on the Information System for Notifiable Diseases (SINAN) regarding 6.707 cases of canine aggression that have occurred in the municipality of Belo Horizonte in the period from 2007 through 2011. The geographical units used for the temporal analysis were its neighborhoods and the nine regional districts. Belo Horizonte is the capital of the state of Minas Gerais which population is made up of 2.375.151 inhabitants (IBGE 2012). It is composed of nine sanitary districts. According to the local canine census of 2010, this population is made up of 279.430 animals (PMBH 2012).

The spatial analysis was obtained through the addresses coordinates that were identified in the SINAN files and it was performed by the internet software Maporama (Maporama 2014), which uses the information related to the addresses and/or the locations Postal Codes (CEP). The same was done regarding patient care settings.

At that moment, 156 (2,3\%) data were eliminated because they indicated Belo Horizonte as a municipality of residence, but their CEP or address corresponded to other municipalities in the Metropolitan Region of Belo Horizonte (RMBH). In addition, 87 (1,3\%) were not used in the evaluation because they were not filled, making it impossible to identify the geographic coordinates.

Some data needed individual verification on Google Maps because $710(10,6 \%)$ coordinates were not identified by Maporama. After the evaluation, those data which have not presented the exact identification of the address were centralized in a located landmark within the district, since the objective was the identification of the regions and possible clusters despite the cartesian exact latitude and longitude of the dog's victims' residences.

In order to identify the health centers' addresses, a spreadsheet that contained information regarding 442 health centers where there is anti-rabies post-exposure prophylactic care in Belo Horizonte 
and RMBH and which was provided by the Secretary of Health of the State of Minas Gerais (SESMG) was used.

After the tabulation of the data, a total of $134(31,8 \%)$ health centers were excluded from the study because the respective codes were not equivalent to those provided by SESMG. The dog aggression cases were punctuated in previously georeferenced address maps of Belo Horizonte and distributed according to the year of occurrence and to the division of the municipality regional districts. The software $\operatorname{ArcGIS}^{\circledR}$ (Programa $\operatorname{ArcGIS}^{\circledR}$ 2014) was used for the map design.

$168(2,5 \%)$ data were excluded from the mapping because they represented individuals who sought care in other cities in the metropolitan region of Belo Horizonte. Only two health centers located in the municipality of Contagem were maintained in the evaluation because they were relevant regarding the number of cases assisted during this research. These cases were considered originated from Belo Horizonte because they occurred in the geopolitical border with Contagem. The service locations were also geoprocessed according to their importance regarding the number of prophylactic visits performed in the period.

The canine population was estimated according to the local census regarding human inhabitants promoted by IBGE (IBGE 2012), which says that there is 1 dog for every 7-10 inhabitants. Thus, canine density maps were created considering "high density" those sites with more than 1000 dogs, "moderate" those between 500 and 1000, and "low" those with less than 500 dogs.

For general verification of the anti-rabies post-exposure care intensity in all regions, maps were made using kernel density techniques, which are considered as a statistical method that analyzes the behavior of some disease or harm according to dot patterns. This method provides the process intensity throughout the region of the study, through functions such as interpolation and smoothing, that associate a numerical value to a point based on the distance of each neighbor event (Anderson 2009; Kloog et al. 2009).

\section{Results}

Among 6.707 cases of canine aggression that have occurred during the period from 2007 through 2011 in Belo Horizonte, properly notified by SINAN, 6.153 (91,74\%) were georeferenced (Figure 1). It was not possible to georeference 554 cases $(8,3 \%)$ because of addresses incompatibility. Exactly 5.797 postexposure treatments were georeferenced and 356 had their location based on a located landmark within the respective district of occurrence.

Figure 1 demonstrates the distribution of canine aggression cases during the five years of this study. It was observed that the frequency of cases showed a heterogeneous distribution, with a higher concentration in the districts: Venda Nova, Norte, Leste, and Centro-Sul.

Children were the most affected group by canine aggression and those sought post-exposure prophylactic treatment for rabies in the period from 2007 to 2011 in Belo Horizonte. It was observed that the cumulative incidence rate was 12,95 cases/10.000 inhabitants between the ages of 5 and 9 years-old and that individuals younger than 15 years-old were the most affected. The accident rate of 1:1771 (one attacked person per 1771 inhabitants) was also observed, according to data recorded for anti-rabies postexposure treatments and reported by SINAN. 


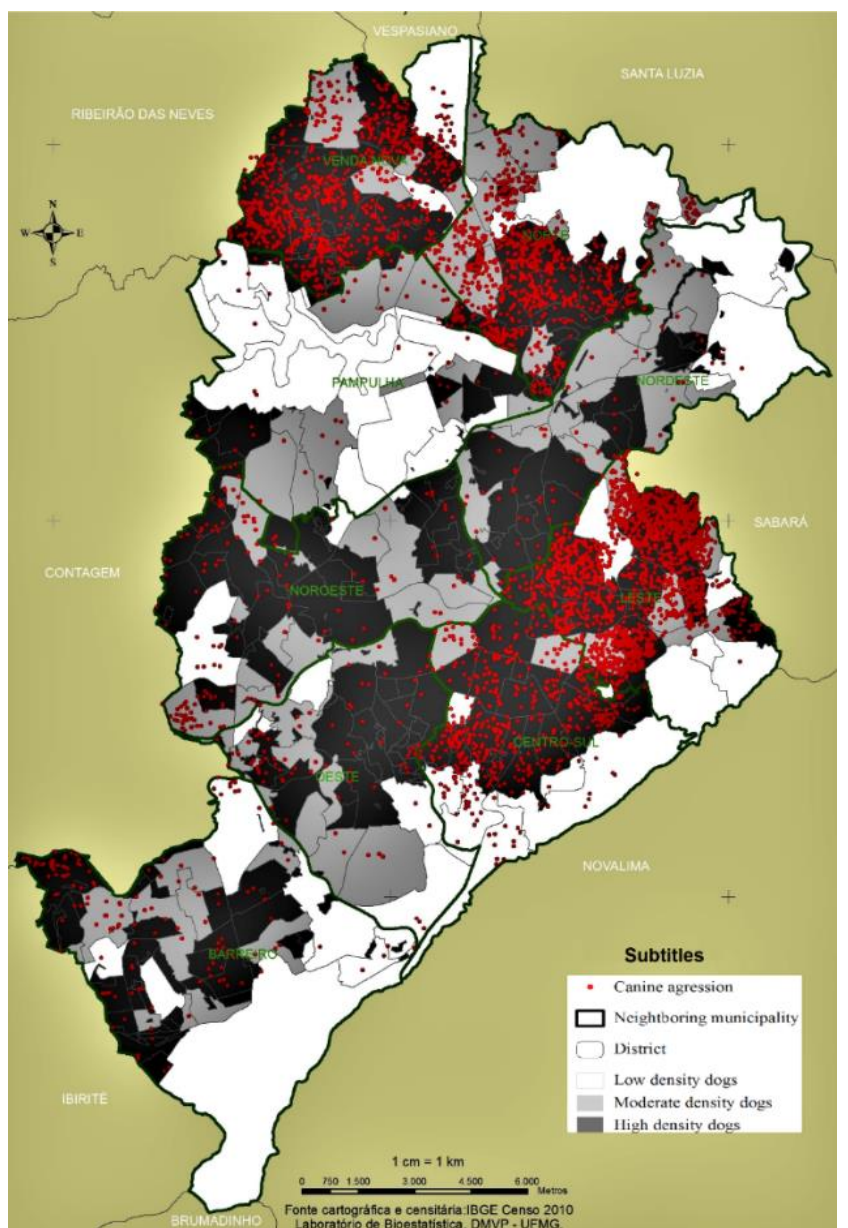

Figure 1. Spatial distribution of aggression cases related to canine density in Belo Horizonte between 2007 to 2011.

Figure 2 shows the spatial distribution of the canine aggression cases reported by SINAN between 2007 and 2011, according to the canine density in each neighborhood and health centers that performed the assistance of the patients. These health centers are well located, which means that they are in the exact regions that presented the highest number of injuries and notified data regarding canine aggression. 


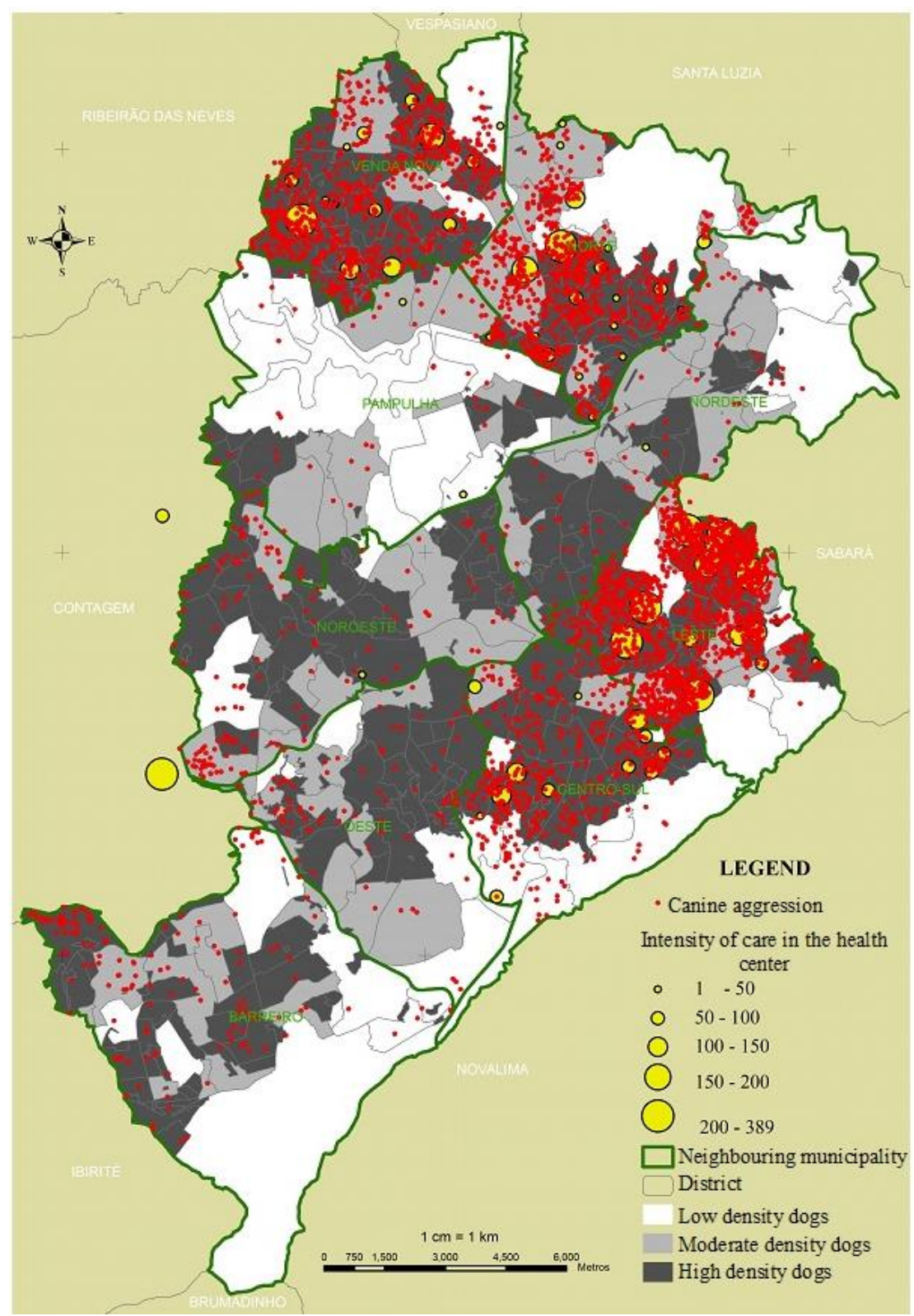

Figure 2. Spatial distribution of the canine aggression and intensity of care in the health center, in Belo Horizonte between 2007 to 2011.

There is a slight decrease in the canine aggression cases in the evaluated period (Figure 3). Figure 4 highlights the four districts that presented the highest concentration of notifications. It is possible to notice that the cases showed a higher concentration in the regions where, in the majority, a high canine population in slums and villages coexists. The four featured districts went through the decentralization process regarding the post-exposure human rabies assistance and carried out the notification of the cases in their own health centers. The evolution of the spatial distribution of the human anti-rabies post-exposure care after canine aggression along the studied five years was regular, that is, there was no increase or expansion of the harm to areas of lower occurrence over time. 


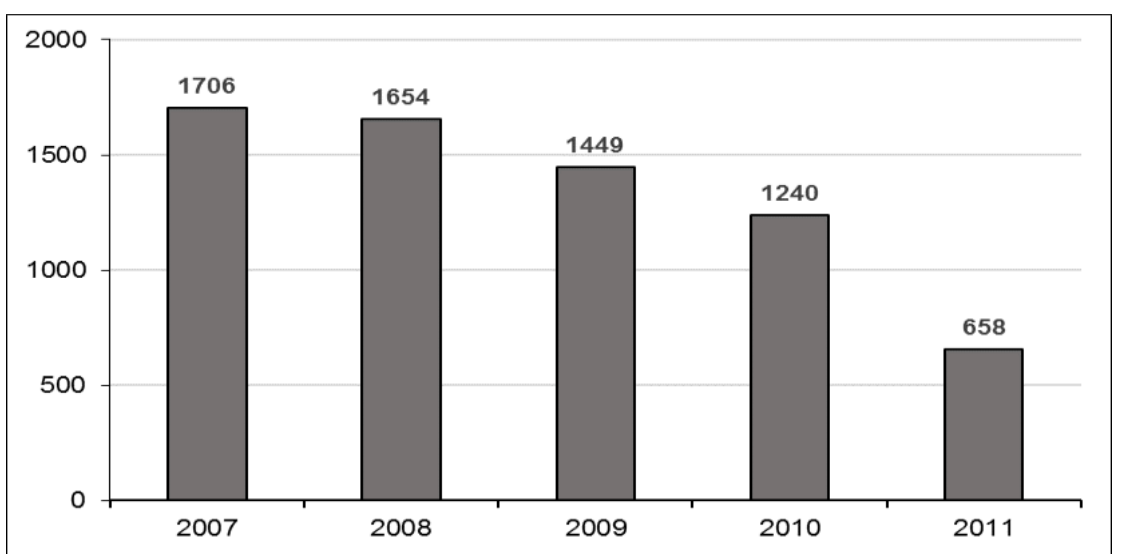

Figure 3. Total anti-rabies post-exposure care distributed between 2007 to 2011 in Belo Horizonte - MG, Brazil.

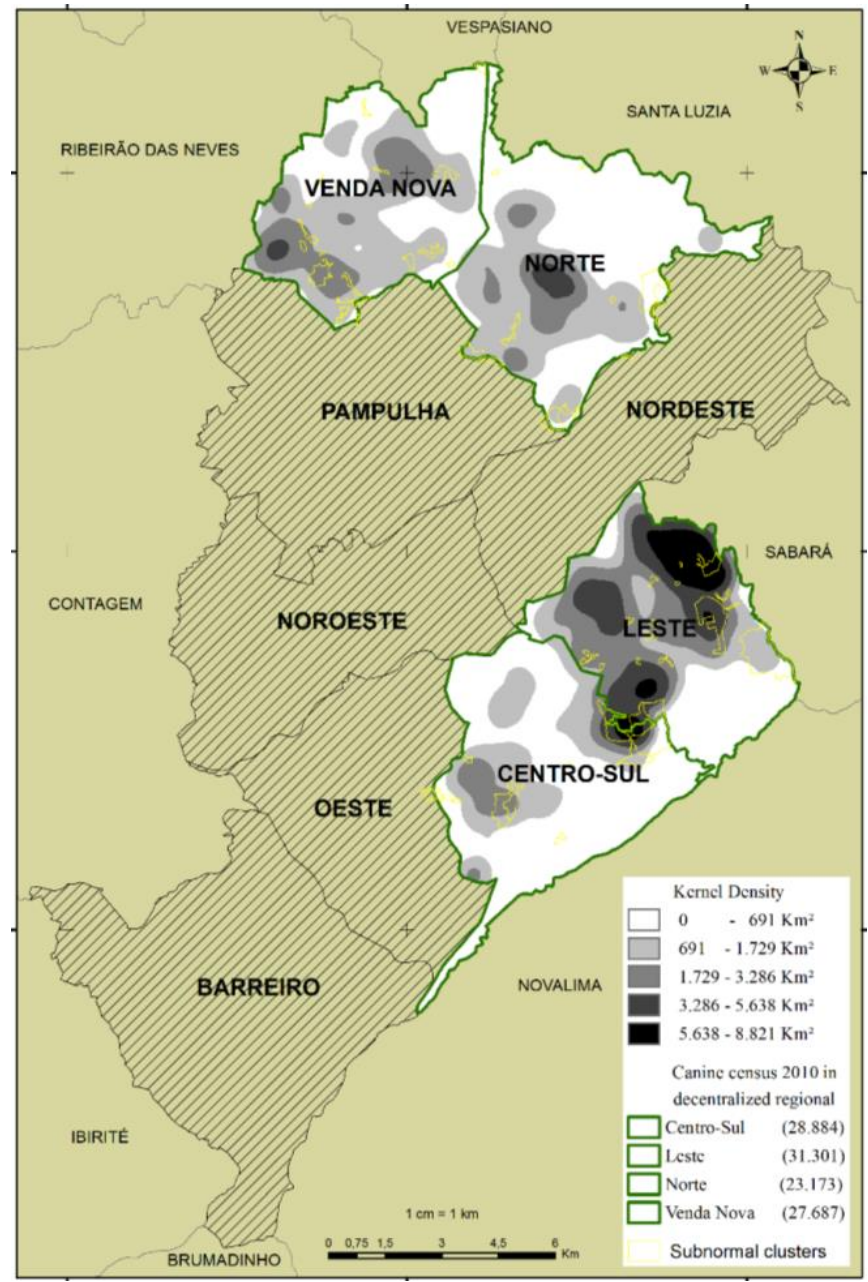

Figure 4. Regional districts with a larger number of aggression cases in relation to the canine population with subnormal clusters in Belo Horizonte between 2007 to 2011.

\section{Discussion}

The cases of canine aggression are directly related to the animal density in the four most affected regions. These results corroborate with several studies that describe dogs as the main aggressor in urban areas (Kloog et al. 2009; Reece et al. 2013; Moreira and Lima 2013; Abreu and Crizóstomo 2014; Mota et al. 2016). The highest occurrences of cases in these regions were due to the difficulty of other districts in reporting dog aggression cases, or even due to the redirection of patients to better-prepared health centers or hospitals. It is suggested that the number of cases may be underestimated since the data refer to people who sought for prophylactic anti-rabies post-exposure care and who were properly notified on SINAN. Patients who were not identified by SINAN might influence a less precise measurement of this indicator. 
Children under 15 years of age were the most affected by canine aggression among the population evaluated in the present study. This result is similar to others that observed respectively in the city of Porto Alegre (RS) and Jaboticabal (SP) (Frias et al. 2011; Veloso et al. 2011), that children are the most affected by canine aggression and those who most seek treatment.

Studies have shown that the attacks by dogs rate in Belo Horizonte can be considered low when compared to other studies conducted in Brazil which demonstrate rates as 1:757 in Osasco (SP), between 1984 and 1994 (Garcia 1999); 1: 313 in Maringá (PR), in 1997 (Carvalho et al. 2002); 1: 239 in Caucaia (CE) and 1: 257 in the State of Ceará, between 2003 and 2005 (Morais et al. 2006); 1: 160 in the municipality of Jaboticabal (SP), from 2000 to 2006 (Frias et al. 2011).

The decentralization process may provide notifications not completely fulfilled since the districts where dog aggression cases are lower usually conduct the patients to seek care at central regions and that might contribute to the occurrence of inconsistencies regarding the data. This was observed in a study carried out in Jaboticabal (SP), in which the authors found the higher intensity of canine aggression in the city central regions, according to spatial analysis (Santos et al. 2017).

The health centers located in the regions with the highest number of assistance and reported cases showed an effective targeting of the patients. Sixty-six $(21,7 \%)$ health centers performed the notification of the studied cases, which has repeated over the years. According to the Law 8080/90 (Brasil 1990), the care decentralization aims to increase the accessibility and to support the care, which might contribute to those actions in certain health centers.

The four districts that most dully notified canine aggression cases are the ones with high canine populations and poorer economical infrastructure - slums and villages (Figure 4). Thus, it can be implied that the lack of information about disease control and behavior that lead to pet responsible ownership may influence epidemiological studies about canine aggression.

Some research demonstrates the importance of health education (Chang et al. 1997; Carvalho et al. 2002; Langoni et al. 2011) mainly regarding rabies prevention. Therefore, the educational work for the general population, focusing on prevention and responsible ownership of animals, reduces the disease risks and canine aggression, since the dogs are currently the most popular pets (Ma et al. 2020).

\section{Conclusions}

It was found that the districts of Venda Nova, Norte, Leste, and Centro Sul were those that presented the highest concentration of the canine aggression cases and post-exposure prophylactic care for rabies in Belo Horizonte. Furthermore, it was possible to verify by the spatial analysis that the decentralization of the post-exposure anti-rabies prophylactic assistance in Belo Horizonte made it possible for the users to access the health system, being this a very important policy in the municipality as a whole and might be the reason for the improvement and agility regarding the health services. It is mandatory to highlight that accessibility and speed of care are important indicators for rabies prevention due to the severity of the disease.

The highest frequency of notifications related to the cases of dog's bites in children might be explained by the concern of the parents or the guardians regarding rabies (since its high lethality), who tend to seek care for post-exposure prophylaxis for the disease in the health centers.

It was observed that the frequency of the human anti-rabies post-exposure prophylaxis decreased during the study period and this fact might be associated with education campaigns and with the incentive of the responsible animals' ownership. Besides, the decrease in street dogs, as a result of the work of retreat the city hall or the adoption of dogs, could reflect in the decrease in post-exposure human anti-rabies prophylactic treatments. Therefore, it is suggested that an integrative action focused on the control of the canine population, health education and epidemiological surveillance studies could contribute to the reduction of canine aggression cases. The performance of a permanent training program for health professionals for the correct fulfillment of the SINAN notification forms regarding the human anti-rabies treatment is also recommended in order to provide quality data for further studies. 
Authors' Contributions: OLIVEIRA, M.A.: conception and design, acquisition of data, drafting the article; OLIVEIRA, T.M.: analysis and interpretation of data, drafting the article; PASTRANA, M.E.O.: analysis and interpretation of data, drafting the article; DUARTE, R.M.: analysis and interpretation of data, drafting the article; DINIZ, S.A.: conception and design, analysis and interpretation of data, drafting the article; SILVA, M.X.: conception and design, analysis and interpretation of data, drafting the article. All authors have read and approved the final version of the manuscript.

Conflicts of Interest: The authors declare no conflicts of interest.

Ethics Approval: Approved by Ethics Committee on Human Research of Federal University of Minas Gerais. CAAE: 30992512.8.0000.5149.

Acknowledgments: The authors would like to thank the funding for the realization of this study provided by the Brazilian agencies FAPEMIG (Fundação de Amparo à Pesquisa do Estado de Minas Gerais - Brasil), and CAPES (Coordenação de Aperfeiçoamento de Pessoal de Nível Superior - Brasil), Finance Code 001.

\section{References}

ABREU, N.A.C. and CRIZÓSTOMO, C.D. Perfil epidemiológico do cliente no atendimento antirrábico humano em Teresina-PI. Revista Interdisciplinar. 2014, 7(2), 103-111.

ANDERSON, T.K. Kernel density estimation and K-means clustering to profile road accident hotspots. Accident Analysis \& Prevention. 2009, 41(3), 359-364. https://doi.org/10.1016/i.aap.2008.12.014

BARBOSA, A.D., et al. Distribuição espacial de acidentes escorpiônicos em Belo Horizonte, Minas Gerais, 2005 a 2009. Arquivo Brasileiro de Medicina Veterinária e Zootecnia. 2014, 66(3), 721-730. https://doi.org/10.1590/16784162-7116

BRASIL. Lei no 8080, de 19 de setembro de 1990. Dispõe sobre as condições para a promoção, proteção e recuperação da saúde, a organização e o funcionamento dos serviços correspondentes, e dá outras providências. Brasília: Diário Oficial da República Federativa do Brasil, 1990.

BRASIL. Ministério da Saúde. Secretaria de Vigilância em Saúde. Departamento de Vigilância Epidemiológica. Normas técnicas de profilaxia da raiva humana. Brasília, 2011.

BRASIL. Ministério da Saúde. Raiva: o que é, causas, sintomas, tratamento, diagnóstico e prevenção. Available from: http://antigo.saude.gov.br/saude-de-a-z/raiva. Accessed 20 Aug 2020

CABRAL, K.C., et al. Avaliação do tratamento antirrábico humano pós-exposição, associado a acidentes com cães. Arquivo Brasileiro de Medicina Veterinária e Zootecnia. 2018, 70(3), 682-688. https://doi.org/10.1590/1678-4162-9292

CARPENTER, T.E. The spatial epidemiologic (r)evolution: a look back in time and forward to the future. Spatial and Spatio-temporal Epidemiology. 2011, 2(3), 119-124. https://doi.org/10.1016/j.sste.2011.07.002

CARVALHO, W.O., SOARES, D.F.P.P. and FRANCESCHI, V.C.S. Características do atendimento prestado pelo serviço de profilaxia da raiva humana na rede municipal de saúde de Maringá-Paraná, no ano de 1997. Informe Epidemiológico do Sus. 2002, 11(1), 25-35. http://dx.doi.org/10.5123/S0104-16732002000100004

CHANG, Y.F., et al. Dog bite incidence in the city of Pittsburgh: a capture-recapture approach. American Journal of Public Health. 1997, 87(10) 1703-1705. https://doi.org/10.2105/ajph.87.10.1703

FRIAS, D.F.R., LAGES, S.L. and CARVALHO, A.A. Avaliação da conduta de profilaxia antirrábica indicada para pessoas envolvidas em agravos com cães e gatos no município de Jaboticabal, SP, no período de 2000 a 2006. Revista Brasileira de Epidemiologia. 2011, 14(4), 722-732. https://doi.org/10.1590/S1415-790X2011000400018

GARC - Global Alliance for Rabies Control. About rabies. 2011. Available from: http://www.rabiescontrol.net/EN/ About-Rabies.html. Accessed $11 \mathrm{abr} .2011$.

GARCIA, R.C.M., et al. Análise de tratamento anti-rábico humano pós exposição em região da Grande São Paulo, Brasil. Revista de Saúde Pública. 1999, 33(3), 295- 301. https://doi.org/10.1590/S0034-89101999000300011

IBGE. IBGE - Instituto Brasileiro de Geografia e Estatística. 2010. Available from: http://www.ibge.gov.br/cidadesat/topwindow.htm?1. Accessed 20 set 2012.

KLOOG, I., HAIM A., and PORTNOV, B.A. Using kernel density function as an urban analysis tool: Investigating the association between nightlight exposure and the incidence of breast cancer in Haifa, Israel. Computers, Environment and Urban System. 2009, 33(1), 55-63. https://doi.org/10.1016/j.compenvurbsys.2008.09.006

LANGONI, H., et al. Conhecimento da população de Botucatu - SP sobre Guarda Responsável de cães e gatos. Veterinária e Zootecnia. 2011, 18(2), 297-305.

MA, G.C., et al. Evaluation of a Dog Population Management Intervention: Measuring Indicators of Impact. Animals (Basel). $2020,10(6), 1061$. https://doi.org/10.3390/ani10061061

MAGALHÃES, M.A.F.M., et al, 2006. Sistemas de Informações Geográficas em saúde. In: SANTOS, S.M. and BARCELLOS, C. (Eds.). Abordagens espaciais na saúde pública. Brasília: Ministério da Saúde, p. 45-62.

MAPORAMA - Available from: http://www.maporama.com/home/. Accessed 10 Mai 2014. 
MENDES, A.C.G., et al. A. Avaliação do Sistema de Informações Hospitalares - SIH/SUS - como fonte complementar na vigilância e monitoramento de doenças de notificação compulsória. Informe Epidemiológico do Sus. 2000, 9(2), 67-86. http://dx.doi.org/10.5123/S0104$\underline{16732000000200002}$

MORAIS, N.B., et al, 2006. The prophylaxis profile of the human rabies in the state of Ceará. In: XVII Reunião Internacional de Raiva nas Américas. Brasília: RITA Inc, p.169.

MOREIRA, A.A.M. and LIMA, M.M. Conduta dos profissionais de saúde pública frente ao atendimento antirrábico humano no Município de Primavera do Leste-MT. Revista de Epidemiologia e Controle de Infecção. 2013, 3(4), 139-143. https://doi.org/10.17058/reci.v3i4.4044

MOTA, R.S.S., et al. Perfil da profilaxia antirrábica humana pré-exposição no estado do Rio Grande do Sul, 2007-2014. Epidemiologia e Serviços de Saúde. 2016, 25(3), 511-518. https://doi.org/10.5123/S1679-49742016000300007

PMBH - Prefeitura Municipal de Belo Horizonte. Vacinação de cães e gatos. 2012. Available from:

http://portalpbh.pbh.gov.br/pbh/ecp/noticia.do. Accessed 15 set 2012.

PROGRAMA ARCGIS. 2014. Available from: https://www.arcgis.com/features/index.html/. Accessed 24 ago 2014.

REECE, J.F., et al. Decline in human dog-bite cases during a street dog sterilisation programme in Jaipur, India. Veterinary Record. 2013, 172(18), 473. https://doi.org/10.1136/vr.101079

ROSADO, B., et al. Spanish dangerous animals act: Effect on the epidemiology of dog bites. Journal of Veterinary Behavior Clinical Applications and Research. 2007, 2(5), 166-174. https://doi.org/10.1016/j.jveb.2007.07.010

ROTHMAN, K.J. A sobering start for the cluster buster's conference. American Journal Epidemiology. 1990, 132(1), 6-13. https://doi.org/10.1093/oxfordjournals.aje.a115790

SANTOS, C.V.B., MELO, R.B. and BRANDESPIM, D.F. Perfil dos atendimentos antirrábicos humanos no agreste pernambucano, $2010-2012$. Epidemiologia e Serviços de Saúde. 2017, 26(1), 161-168. https://doi.org/10.5123/S1679-49742017000100017

SCHNEIDER, M.C., et al. Controle da raiva no Brasil de 1980 a 1990. Revista de Saúde Pública. 1996, 30(2), 196-203. https://doi.org/10.1590/S0034-89101996000200012

VELOSO, R.D., et al. Perfil epidemiológico do atendimento antirrábico humano em Porto Alegre, RS, Brasil. Cadernos de Saúde Pública. 2011, 16(12), 4875-4884. https://doi.org/10.1590/S1413-81232011001300036

Received: 23 April 2020 | Accepted: 26 October 2020 | Published: 29 December 2021

This is an Open Access article distributed under the terms of the Creative Commons Attribution License, which permits unrestricted use, distribution, and reproduction in any medium, provided the original work is properly cited. 